\title{
Emotional Experience of Consumption of Fast Food-A Study of College Students in Sultanate of Oman
}

\author{
T. Kalakumari*, Saed Adnan Mustafa, Randolf Von Narbay Salindo \\ Department of Business Administration, Sur University College, Sur, Sultanate of Oman \\ Email: *kalakumarit@gmail.com
}

How to cite this paper: Kalakumari, T., Saed, A.M. and Salindo, R.V.N. (2020) Emotional Experience of Consumption of Fast Food-A Study of College Students in Sultanate of Oman. Open Journal of Business and Management, 8, 452-466. https://doi.org/10.4236/ojbm.2020.82028

Received: December 23, 2019

Accepted: February 1, 2020

Published: February 4, 2020

Copyright $\odot 2020$ by author(s) and Scientific Research Publishing Inc. This work is licensed under the Creative Commons Attribution International License (CC BY 4.0).

http://creativecommons.org/licenses/by/4.0/

cc) (i) Open Access

\begin{abstract}
In the present scenario, most of the peoples are consuming fast food items for the purpose of solving the cooking hazards. These fast food items are consumed by different age wise people like children, adults, young and old to eat the food in a tasty manner. The Pew Research Center report shows that, there are 50 million Americans who eat fast food daily. In the US, the value of food trade is about 198.9 billion US\$. By the year 2020, this figure is anticipated to travel on the far side 223 billion. The advance development of fast food business has created different household brand names, such as McDonald's, KFC and other similar brands. McDonald's, Pizza Hut and KFC yield maximum revenue in the fast food business. Nowadays a variety of fast food items is consumed by people. Fast food products are prominently sold in small coffee shops and other restaurants. The choice of selecting a fast food item is very difficult for consumers. Thus, consumers take utmost care in selecting a fast food product. In short, majority of the consumers focus on qualitative and innovative fast food items. Consumers' choices may be varied based on their demographic and psychological characteristics. Majority of the students always use fast food items in the morning, noon and evening to fulfill their needs. This paper shows that the consumer perspective and buying pattern of fast food products consumed by college students are emotional in their day to day life.
\end{abstract}

\section{Keywords}

Consumer Behaviour, Emotional Experience, Fast Food, Influential Factors

\section{Introduction}

In the present scenario, most of the peoples are consuming fast food items for 
the purpose of solving the cooking hazards. These fast food items are consumed by different age wise people like children, adults, young and old to eat the food in a tasty manner [1]. The research report according to Pew shows that, Americans eat fast food daily with approximately 50 billion. In the US, the value of food trade is just about 198.9 billion US dollars [2]. By 2020, this figure is anticipated to travel on the far side 223 billion. The thought of this massive market consists of restaurants and drive-thrus, cafeterias and buffets. Generally the fast food manufacturing corporation has produced a number of brand names, both nationally and internationally. The main familiar fast food industry is McDonald's with a brand value of 88 billion US dollars and above [3]. In 2016, the most valuable fast food brand in the world was McDonald's and KFC. In 2015, McDonald's was also the biggest fast food corporation in terms of profits, followed by Sandwich and Yum Brands, parent of Taco Bell and Pizza Hut.

Fast food could also be a straight forward choice for school and college students [4]; its nutritional content positively won't offer energy to you. Usually, a fast food meal is worth [5] 37\% of your daily calorie intake, $33.6 \%$ of daily fat, and $15.4 \%$ of daily protein. As food trends quickly shift to healthier choices, it seems that the food business is maintaining the pace. This booming business wins the hearts of fifty million Americans each day.

Nowadays a variety of fast food items is consumed by people. Fast food products are prominently sold in small coffee shops and small and medium restaurants. The choice of selecting a fast food item is very difficult for consumers. Thus, consumers take utmost care in selecting a fast food product [6]. In short, majority of the consumers focus on qualitative and innovative fast food items. Consumers' choices may be varied based on their demographic and psychological characteristics.

Majority of the students always use fast food items in the morning, noon and evening to fulfill their needs [7]. This paper shows that the emotional experience of fast food products is used by college students in their day to day life.

\subsection{Problem Statement}

In the modern world, college students are facing lots of troubles in their health. Modern fast food products influence students through different creative and innovative food items [8]. The cost of fast food is comparatively small and tastes are excellent; however the harmful impacts are on human health much longer than these direct concerns [9]. The content of high calorie meals moves toward heavy weight, cholesterol, salt and sugar-and therefore it leads to fewer vitamins, minerals and other nutrients in the human body than in good health foods [10]. The health issues that stem from overweight and fat alone will severely limit lifestyles and shorten life spans. Hence, this paper aims to analyze the purpose of using fast food, factors impressed the students to buy the fast food items and examine the emotional experience of consumption of fast food items used by the college students in their daily life. 


\subsection{Objectives of the Study}

1) To study the emotional experience of utilization of fast food.

2) To identify the purpose of using fast food items by college students.

3) To analyze the factors impressed the students to buy fast food items.

\section{Review of Literature}

Anita [11] Goyal and N. P. Singh (2008), have inspected the customer discernment about inexpensive food in India and they have discovered that youthful Indian has enthusiasm for visiting cheap food outlets for entertainment only and change yet home nourishment their first decision. Buyer attributes impacting inexpensive food utilization in Turkey was researched by Cuma [12] Akbay, Gulgun Yildiz Tiryaki and Aykut Gul (2007) and the outcomes indicated that age, pay, instruction, family unit size, nearness of youngsters and different factors altogether impact the inexpensive food utilization conduct in Turkey.

Another investigation has made by Elizabeth [13] Denney-Wilson, Anthony D. Okely, Louise Hardy, David Crawford and Timothy Dobbins (2009) on effects on utilization of soda pops and quick nourishments youths in New South Wales and their outcomes demonstrated that over portion of the young men and more than $33 \%$ of the young ladies detailed drinking soda pops every day, and utilization topped in grade eight understudies in the investigation zone.

Another examination has done by Bala Swamy [14], Anil Kumar and Srinivasa Rao (2012) have investigated the purchasing conduct of shoppers towards moment nourishment items in India and their outcomes recommend that the normal per capita buy and per capita use on moment nourishment items had a positive association with pay of family units. A past report has done by Vinit [15] Dani and Vanishree Pabalkar (2013) with respect to on investigating of purchaser conduct towards inexpensive food industry in Pune and their discoveries uncovers that Indian cheap food showcase is developing at a yearly development pace of $30 \%-35 \%$ and other famous natural pecking order have colossal plans of extension in future.

Anand, (2011) [16] said that, the youngsters had been fonder of setting off to the drive-through joints for having a ton of fun on certain events like birthday events, results and even together parties. The adolescents accepted that Fast nourishments tastes are so delectable great to those youths, which cause them to accept that inexpensive food is speedy, simple and fulfilling as cheap food focuses had been making "esteem" dinners for kids that are expanded in parcel measures and turning into a design, as clients are eating as well as appreciating the earth.

\section{Research Design}

In the exploration configuration process, the specialist received helpful examining strategy for gathering information. The understudies were chosen and it was guaranteed that the individuals are exceptionally utilizing the inexpensive food 
things in their everyday life. On receiving this technique absolutely two universities were chosen from Sultanate of Oman. From every school 82 understudies were chosen. So the proposed test size of 164 understudies is taken up for the examination. As needs be, 164 polls were gathered and 14 surveys were avoided because of a lot of missing information. Subsequently, 150 substantial polls were utilized for the investigation.

\section{Sources of Data Collection}

This exploration comprises of both essential and auxiliary information. Survey strategy was pursued for gathering the information. Essential information for this exploration was gathered through surveys and direct vis-à-vis discussion among the respondents. Optional information for this investigation was created from the web, various periodicals, books, magazines and the legislative distributed archives.

\section{Data Analysis and Interpretation}

Table 1 infers that, majority of the respondents procure fast food for saving time, it is graded in main position with the average score of 3.60. Subsequently, it is observed that the respondents' are purchasing fast food for opting variety of menu; it is rated in second position with an average score of 3.59. Further, the sample subjects consume fast food for fun; it is graded in third position with the mean score of 3.56. Further it is observed that the sample respondents are procuring fast food for fewer prices and for other reasons like delicious, and convenient to eat in different places. The rest of the variables are graded in fourth, fifth and sixth position with an average score of $3.49,3.43$ and 3.33 respectively.

From Table 1 it is proved that, greater part of the respondents procure fast food for time saving purpose, it is graded in the first position with the average score of 3.60 .

H1: There exists no relationship between demographic status of college students and the purposes stated by them for consuming the fast food.

From Table 2, the results of computed ANOVA test values $(3.729,0.823$, 1.568 and 1.278) are not found to significant at five per cent and rejected hypothesis. It has been confirmed that there exists relationship between gender of students and the purposes stated by them for consuming the fast food.

Table 3 shows that, the results of computed ANOVA test values $(0.251,1.208$, 4.468 and 1.911) are not found to significant at five per cent and rejected hypothesis. It has been declared that there exists relationship between age of students and the purposes stated by them for consuming the fast food.

From Table 4, it has been proved that the results of computed ANOVA test values (3.154, 0.520, 0.016 and 0.559$)$ are not found to significant at five per cent and rejected hypothesis. It has been confirmed that there exists relationship between marital status of students and the purposes stated by them for consuming the fast food. 
The results of computed ANOVA test values (13.142, 8.216, 2.938 and 10.922) in Table 5 are found to significant at five per cent and accepted hypothesis. It has been declared that there exists no relationship between education level of students and the purposes stated by them for consuming the fast food.

Table 1. Purpose of consuming fast food.

\begin{tabular}{ccccc}
\hline Sl. No & Purpose of Using Fast Food & Sum & Mean & Rank \\
\hline 1. & Saves Time & 540 & 3.60 & 1 \\
2. & Variety of Menu & 538 & 3.59 & 2 \\
3. & Convenient & 500 & 3.33 & 6 \\
4. & Delicious & 514 & 3.43 & 5 \\
5. & For Fun & 534 & 3.56 & 4 \\
6. & Inexpensive & 524 & 3.49 & 4 \\
\hline
\end{tabular}

Source: Primary Data.

Table 2. Result of summary of statistics and one-way ANOVA association between gender of students and purposes stated by them for consuming the fast food.

\begin{tabular}{ccccccc}
\hline \multirow{2}{*}{ Variables } & \multicolumn{2}{c}{ Male } & \multicolumn{2}{c}{ Female } & S Value & Sig \\
\cline { 2 - 6 } & Mean & SD & Mean & SD & & 0.055 \\
Saves Time & 4.167 & 1.367 & 3.458 & 1.887 & 3.729 & 0.366 \\
Variety of Menu & 3.833 & 1.599 & 3.525 & 1.680 & 0.823 & 0.212 \\
Convenient & 3.000 & 1.661 & 3.417 & 1.622 & 1.568 & 0.001 \\
Delicious & 2.500 & 1.526 & 3.658 & 1.627 & 12.460 & 0.001 \\
For Fun & 4.333 & 1.516 & 3.367 & 1.705 & 8.046 & $\mathbf{0 . 0 0 5}$ \\
Inexpensive & 3.167 & 1.895 & 3.575 & 1.738 & 1.278 & 0.260 \\
\hline
\end{tabular}

Level of Significance: 5 per cent.

Table 3. Result of summary statistics and one-way ANOVA association between age of students and purposes stated by them for consuming the fast food.

\begin{tabular}{|c|c|c|c|c|c|c|c|c|c|c|}
\hline \multirow{2}{*}{ Variables } & \multicolumn{2}{|c|}{16 - 20 Years } & \multicolumn{2}{|c|}{21 - 25 Years } & \multicolumn{2}{|c|}{26 - 30 Years } & \multicolumn{2}{|c|}{$\begin{array}{c}30 \text { Years } \\
\text { and Above }\end{array}$} & \multirow{2}{*}{$\begin{array}{c}\mathrm{F} \\
- \text { Value }\end{array}$} & \multirow{2}{*}{ Sig } \\
\hline & Mean & SD & Mean & SD & Mean & SD & Mean & $\mathrm{SD}$ & & \\
\hline Saves Time & 3.565 & 1.974 & 3.680 & 1.647 & 3.600 & 1.813 & 2.973 & 1.307 & 0.251 & 0.861 \\
\hline Variety of Menu & 3.794 & 1.426 & 3.220 & 1.844 & 3.587 & 1.664 & 3.293 & 1.126 & 8.403 & 0.000 \\
\hline Convenient & 3.304 & 1.636 & 3.440 & 1.567 & 3.333 & 1.633 & 3.047 & 1.150 & 4.486 & 0.005 \\
\hline Delicious & 3.424 & 1.528 & 3.580 & 1.980 & 3.427 & 1.668 & 3.455 & 1.150 & 1.208 & 0.309 \\
\hline For Fun & 3.641 & 1.635 & 3.340 & 1.780 & 3.560 & 1.709 & 3.360 & 1.200 & 4.468 & 0.105 \\
\hline Inexpensive & 3.272 & 1.967 & 3.740 & 1.411 & 3.493 & 1.771 & 3.209 & 1.296 & 1.911 & 0.130 \\
\hline
\end{tabular}

Level of Significance: 5 per cent. 
Table 4. Result of summary statistics and one-way ANOVA association between marital status of students and purposes stated by them for consuming the fast food.

\begin{tabular}{cccccccc}
\hline \multirow{2}{*}{ Variables } & \multicolumn{2}{c}{ Married } & \multicolumn{2}{c}{ Unmarried } & \multirow{2}{*}{ F Value } & \multirow{2}{*}{ Sig } \\
\cline { 2 - 5 } & Mean & SD & Mean & SD & & \\
\hline Saves Time & 2.500 & 1.604 & 3.662 & 1.810 & 3.154 & 0.078 \\
Variety of Menu & 4.000 & 2.138 & 3.563 & 1.639 & 0.520 & 0.472 \\
Convenient & 2.000 & 1.069 & 3.409 & 1.629 & 5.816 & 0.017 \\
Delicious & 3.500 & 0.535 & 3.423 & 1.711 & 0.016 & 0.899 \\
For Fun & 4.000 & 2.138 & 3.535 & 1.687 & 0.559 & 0.456 \\
Inexpensive & 3.409 & 1.783 & 3.493 & 1.771 & 6.333 & $\mathbf{0 . 0 1 3}$ \\
\hline
\end{tabular}

Level of Significance: 5 per cent.

Table 5. Result of summary statistics and one-way ANOVA association between education level of students and purposes stated by them for consuming the fast food.

\begin{tabular}{|c|c|c|c|c|c|c|c|c|c|c|}
\hline \multirow{2}{*}{ Variables } & \multicolumn{2}{|c|}{ School } & \multicolumn{2}{|c|}{ Diploma } & \multicolumn{2}{|c|}{ Graduate } & \multicolumn{2}{|c|}{ Post Graduate } & \multirow{2}{*}{$\begin{array}{c}\text { F } \\
\text { Value }\end{array}$} & \multirow{2}{*}{ Sig } \\
\hline & Mean & $\mathrm{SD}$ & Mean & SD & Mean & SD & Mean & SD & & \\
\hline Saves Time & 5.409 & 0.796 & 3.253 & 1.677 & 3.759 & 1.994 & 2.000 & 1.069 & 13.142 & 0.000 \\
\hline Variety of Menu & 4.046 & 0.653 & 3.615 & 1.919 & 3.448 & 1.404 & 2.500 & 0.535 & 1.800 & 0.150 \\
\hline Convenient & 2.409 & 1.469 & 3.308 & 1.590 & 3.517 & 1.526 & 5.500 & 0.535 & 8.216 & 0.000 \\
\hline Delicious & 3.364 & 1.497 & 3.418 & 1.521 & 3.069 & 2.137 & 5.000 & 1.069 & 2.938 & 0.035 \\
\hline For Fun & 3.318 & 1.555 & 3.374 & 1.710 & 4.069 & 1.889 & 4.500 & 0.535 & 2.226 & 0.088 \\
\hline Inexpensive & 2.455 & 1.969 & 4.033 & 1.735 & 3.138 & 0.990 & 1.500 & 0.535 & 10.922 & 0.000 \\
\hline
\end{tabular}

Level of Significance: 5 per cent.

From Tables 2-4 it has been cleared that the results of computed ANOVA test values (gender, age and marital status) are not found to significant at five per cent and rejected hypothesis. It has been confirmed that there exists association between demographic status of college students and the purposes stated by them for consuming the fast food.

Table 6 clearly shows the Factor analysis relating to the factors impressed students to buy the fast food. Considered twelve variables are: freshness, hygiene, nutritious, low fat content, rich fat content, reasonable price, different varieties, advertisement, emotional satisfaction, taste, healthy product and economical.

Five factors extracted on Table 7 together account for 84.334 per cent of the total variance (information contained in the original twelve variables).

1) Hygiene Factor: Freshness, hygiene, taste and healthy product are grouped as first factor and it is valid for 38.499 per cent of the total variance.

2) Price \& Variety: Reasonable price and different varieties comprise the second factor and it's comprised for 14.498 per cent of the total variance.

3) Promotions: Low fat content and advertisement comprise the third factor and it's measured for 12.567 per cent of the total variance. 
Table 6. Factors impressed students to buy the fast food.

\begin{tabular}{ccccc}
\hline Sl. No & Factors & Sum & Mean & Rank \\
\hline 1. & Freshness & 1004 & 6.69 & 6 \\
2. & Hygiene & 1118 & 7.45 & 2 \\
3. & Nutritious & 820 & 5.47 & 11 \\
4. & Low Fat Content & 981 & 6.54 & 7 \\
5. & Rich Fat Content & 865 & 5.77 & 9 \\
6. & Reasonable Price & 1053 & 7.02 & 4 \\
7. & Different Varieties & 1070 & 7.13 & 3 \\
8. & Advertisement & 1031 & 6.87 & 5 \\
9. & Emotional Satisfaction & 903 & 6.02 & 8 \\
10. & Taste & 1191 & 7.94 & 1 \\
11. & Healthy Product & 814 & 5.43 & 12 \\
12. & Economical & 850 & 5.67 & 10 \\
\hline
\end{tabular}

Source: Primary Data.

Table 7. Rotated component matrix factors impressed students to buy the fast food.

\begin{tabular}{|c|c|c|c|c|c|}
\hline \multirow[b]{2}{*}{ Variables } & \multicolumn{5}{|c|}{ Factors } \\
\hline & $\begin{array}{c}\text { Hygiene } \\
\text { Factor }\end{array}$ & $\begin{array}{l}\text { Price \& } \\
\text { Variety }\end{array}$ & Promotions & $\begin{array}{l}\text { Health } \\
\text { Factors }\end{array}$ & $\begin{array}{l}\text { Nutritious\& } \\
\text { Satisfaction }\end{array}$ \\
\hline $\mathrm{X}_{1}$-Freshness & 0.849 & - & - & - & - \\
\hline $\mathrm{X}_{2}$-Hygiene & 0.811 & - & - & - & - \\
\hline $\mathrm{X}_{3}$-Nutritious & - & - & - & - & 0.931 \\
\hline $\mathrm{X}_{4}$-Low Fat Content & - & - & - & 0.927 & - \\
\hline $\mathrm{X}_{5}$-Rich Fat Content & - & - & - & 0.838 & - \\
\hline $\mathrm{X}_{6}$-Reasonable Price & - & 0.819 & - & - & - \\
\hline $\mathrm{X}_{7}$-Different Varieties & - & 0.787 & - & - & - \\
\hline $\mathrm{X}_{8}$-Advertisement & - & - & 0.662 & - & - \\
\hline $\mathrm{X}_{9}$-Emotional Satisfaction & - & - & - & - & 0.583 \\
\hline $\mathrm{X}_{10}$-Taste & 0.645 & - & - & - & - \\
\hline $\mathrm{X}_{11}$-Healthy Product & 0.570 & - & - & - & - \\
\hline $\mathrm{X}_{12}$-Economical & - & - & - & 0.767 & - \\
\hline Eigen Value & 4.420 & 1.740 & 1.508 & 1.319 & 0.933 \\
\hline$\%$ of Variance & 38.499 & 14.498 & 12.567 & 10.995 & 7.775 \\
\hline Cumulative & 38.499 & 52.997 & 65.564 & 76.559 & 84.334 \\
\hline
\end{tabular}

Level of Significance: 5 per cent.

4) Health Factors: Rich fat content and economical composes the fourth factor and it's measured for 10.995 per cent of the total variance.

5) Nutritious \& Satisfaction: Nutritious and emotional satisfaction 
represents the fifth factor and it financial statement for $7.775 \%$ of the total variance.

From the above Figure 1, it has been experimented that although there are twelve primary components only 4 factors have Eigen values over one.

Table 8 shows the alpha values and indicates significant correlation and internal consistency between the variables tested. Reliability analysis' Cronbach's Alpha values for the factors that persuade the emotional consumption of fast food were grouped under five heads: factor I (0.829), factor II (0.803), factor III (0.780), factor IV (0.743) and factor V (0.662).

Tables 9-11 show the emotional experience of students and their consumption patterns according to five strategic experiential modules and it has been summarized in Table 12. It shows the Kaiser-Mayer-Olkin test and it's based on the correlation and partial correlation of the variables. Out of twenty five variables considered it has been found that the value of test statistic is 0.895 , which means the factor analysis for the identified variables is found to be appropriate to the data. The Bartlett's test of sphericity chi-square (3303.181) is used to test whether the correlation matrix is an identity matrix. Here the significant value is 0.000 which indicates that there exits significant relationship among the variables.

Table 13 and Table 14 clearly depict the Rotated component matrix for students emotional experience of consumption of fast food and all five factors derived together account for $86.836 \%$ of the total variance (information contained in the original twenty five variables).

Table 15 shows the summary of Reliability analysis's Cronbach's Alpha values for the factors that influence the consumption of fast food were grouped under five heads: strongly agree (0.946), agree (0.897), neutral (0.855), disagree (0.845) and strongly disagree $(0.837)$. The alpha values indicate significant correlation and internal consistency between the variables tested.

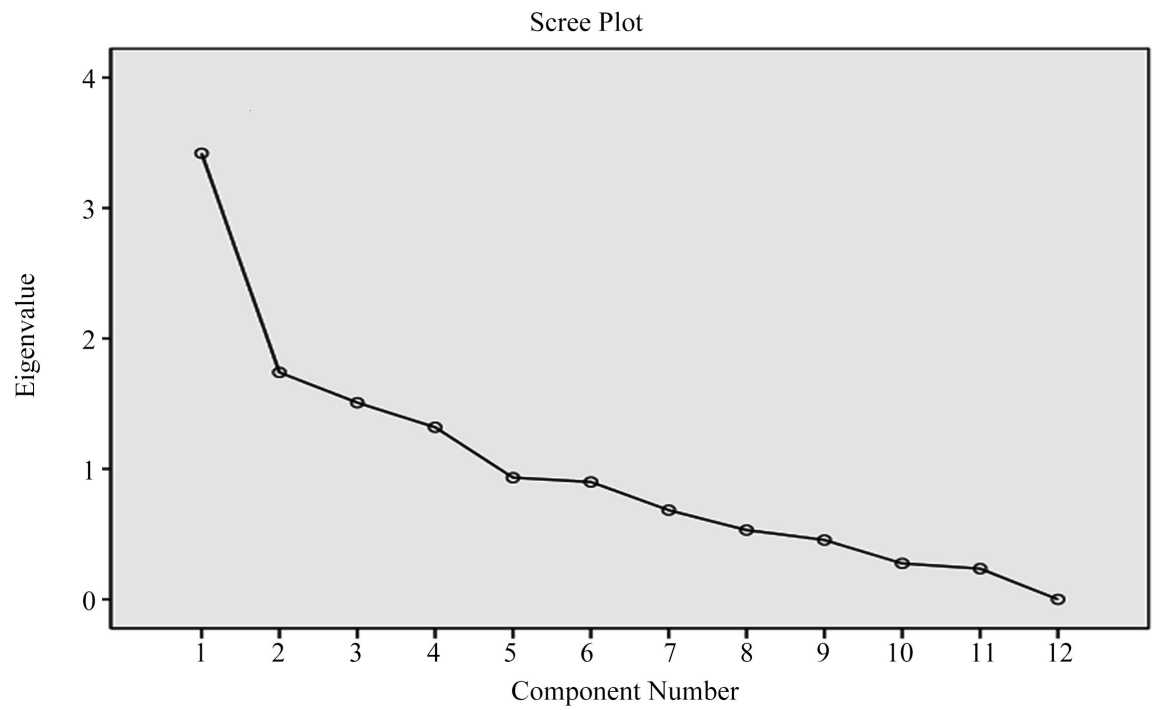

Figure 1. Scree plot factors impressed students to buy the fast food. 
Table 8. Summary of rotation factor analysis \& Cronbach's alpha factors impressed college students to buy the fast food.

\begin{tabular}{ccc}
\hline Factors & Variables included in the factors & Cronbach's Alpha \\
\hline Hygiene Factor & Freshness, hygiene, taste and healthy product & 0.829 \\
Price \& Variety & Reasonable price and different varieties & 0.803 \\
Promotions & Low fat content and advertisement & 0.780 \\
Health Factors & Rich fat content and economical & 0.743 \\
Nutritious \& Satisfaction & Nutritious and emotional satisfaction & 0.662 \\
\hline
\end{tabular}

Source: Computed From Primary Data.

Table 9. Students emotional experience of consumption of fast food.

\begin{tabular}{|c|c|c|c|c|c|c|c|c|}
\hline Variables & $\begin{array}{l}\text { Strongly } \\
\text { Agree }\end{array}$ & Agree & Neutral & Disagree & $\begin{array}{l}\text { Strongly } \\
\text { Disagree }\end{array}$ & Sum & Mean & Rank \\
\hline \multicolumn{9}{|l|}{ Sense Experience } \\
\hline $\begin{array}{l}\text { Quality of Fast Food is } \\
\text { Really Good }\end{array}$ & $\begin{array}{l}39 \\
(26.00)\end{array}$ & $\begin{array}{l}43 \\
(28.67)\end{array}$ & $\begin{array}{l}29 \\
(19.33)\end{array}$ & $\begin{array}{l}26 \\
(17.33)\end{array}$ & $\begin{array}{l}13 \\
(8.67)\end{array}$ & 519 & 3.46 & 4 \\
\hline $\begin{array}{l}\text { Creation of Fast Food are } \\
\text { Simple }\end{array}$ & $\begin{array}{l}29 \\
(19.33)\end{array}$ & $\begin{array}{l}74 \\
(49.33)\end{array}$ & $\begin{array}{l}20 \\
(13.33)\end{array}$ & $\begin{array}{l}27 \\
(18.00)\end{array}$ & $\begin{array}{l}0 \\
(0.00)\end{array}$ & 555 & 3.70 & 1 \\
\hline $\begin{array}{l}\text { Fast Food Assure Your } \\
\text { Health in the form Good } \\
\text { Strength }\end{array}$ & $\begin{array}{l}44 \\
(29.33)\end{array}$ & $\begin{array}{l}28 \\
(18.67)\end{array}$ & $\begin{array}{l}19 \\
(12.67)\end{array}$ & $\begin{array}{l}35 \\
(23.33)\end{array}$ & $\begin{array}{l}24 \\
(16.00)\end{array}$ & 483 & 3.22 & 5 \\
\hline $\begin{array}{l}\text { The Overall Performance } \\
\text { of Fast Food Let You Feel } \\
\text { Joyfully Satisfies }\end{array}$ & $\begin{array}{l}31 \\
(20.67)\end{array}$ & $\begin{array}{l}63 \\
(42.00)\end{array}$ & $\begin{array}{l}29 \\
(19.33)\end{array}$ & $\begin{array}{l}22 \\
(14.67)\end{array}$ & $\begin{array}{l}5 \\
(3.33)\end{array}$ & 543 & 3.62 & 2 \\
\hline $\begin{array}{l}\text { The Minimum Quantity } \\
\text { of Fast Food Can Enough } \\
\text { one Time Lunch or Snacks }\end{array}$ & $\begin{array}{l}30 \\
(20.00)\end{array}$ & $\begin{array}{l}65 \\
(43.33)\end{array}$ & $\begin{array}{l}25 \\
(16.67)\end{array}$ & $\begin{array}{l}21 \\
(14.00)\end{array}$ & $\begin{array}{l}9 \\
(6.00)\end{array}$ & 536 & 3.57 & 3 \\
\hline
\end{tabular}

\section{Feel Experience}

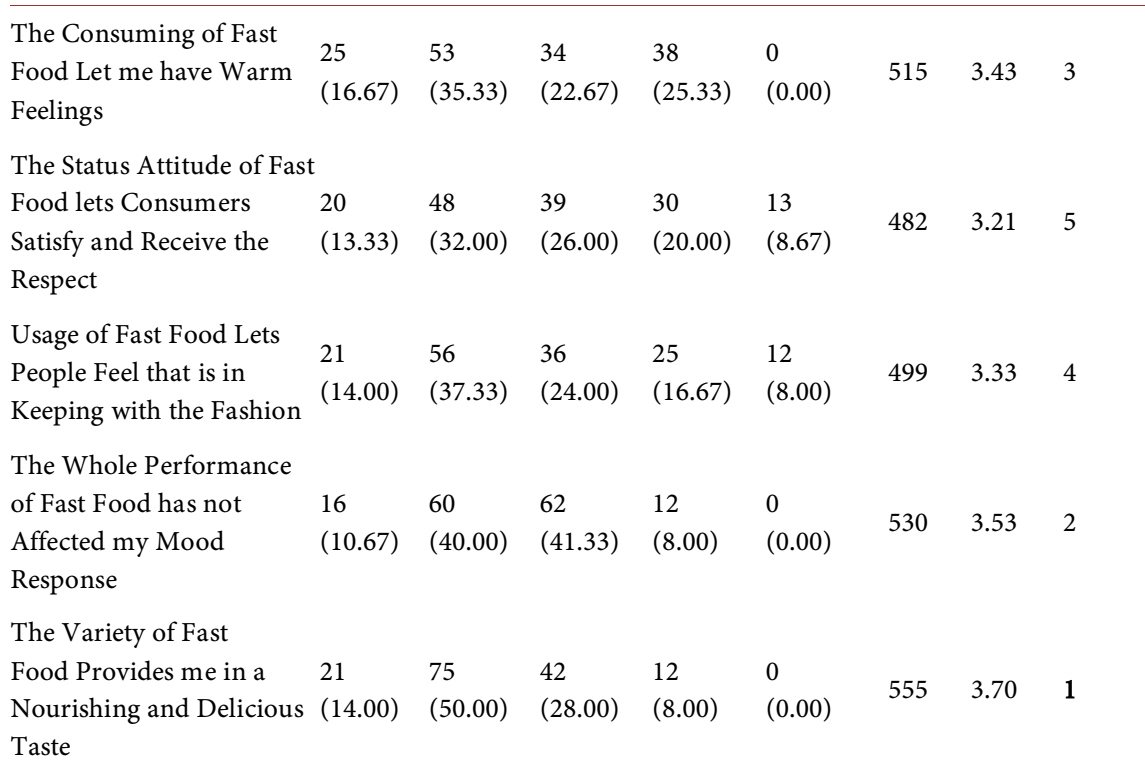

Source: Primary Data. 
Table 10. Students emotional experience of consumption of fast food.

\begin{tabular}{|c|c|c|c|c|c|c|c|c|}
\hline Variables & $\begin{array}{l}\text { Strongly } \\
\text { Agree }\end{array}$ & Agree & Neutral & Disagree & $\begin{array}{l}\text { Strongly } \\
\text { Disagree }\end{array}$ & Sum & Mean & Rank \\
\hline \multicolumn{9}{|l|}{ Think Experience } \\
\hline $\begin{array}{l}\text { Fast Food can Stimulate } \\
\text { my Curiosity }\end{array}$ & $\begin{array}{l}39 \\
(26.00)\end{array}$ & $\begin{array}{l}28 \\
(18.67)\end{array}$ & $\begin{array}{l}49 \\
(32.67)\end{array}$ & $\begin{array}{l}30 \\
(20.00)\end{array}$ & $\begin{array}{l}4 \\
(2.67)\end{array}$ & 518 & 3.45 & 1 \\
\hline $\begin{array}{l}\text { Fast Food Make } \\
\text { Consumers Feel } \\
\text { Surprising }\end{array}$ & $\begin{array}{l}29 \\
(19.33)\end{array}$ & $\begin{array}{l}38 \\
(25.33)\end{array}$ & $\begin{array}{l}34 \\
(22.67)\end{array}$ & $\begin{array}{l}25 \\
(16.67)\end{array}$ & $\begin{array}{l}24 \\
(16.00)\end{array}$ & 473 & 3.15 & 3 \\
\hline $\begin{array}{l}\text { Fast Food can Stimulate } \\
\text { me the thinking of Other } \\
\text { Related thing Like Health } \\
\text { Immune System and } \\
\text { Source of Energy etc. ... }\end{array}$ & $\begin{array}{l}31 \\
(20.67)\end{array}$ & $\begin{array}{l}25 \\
(16.67)\end{array}$ & $\begin{array}{l}40 \\
(26.67)\end{array}$ & $\begin{array}{l}24 \\
(16.00)\end{array}$ & $\begin{array}{l}30 \\
(20.00)\end{array}$ & 453 & 3.02 & 5 \\
\hline $\begin{array}{l}\text { Fast Food can Stimulate } \\
\text { my Imagination }\end{array}$ & $\begin{array}{l}34 \\
(22.67)\end{array}$ & $\begin{array}{l}43 \\
(28.67)\end{array}$ & $\begin{array}{l}21 \\
(14.00)\end{array}$ & $\begin{array}{l}34 \\
(22.67)\end{array}$ & $\begin{array}{l}18 \\
(12.00)\end{array}$ & 491 & 3.27 & 2 \\
\hline $\begin{array}{l}\text { Fast Food can Stimulate } \\
\text { my Creative thinking }\end{array}$ & $\begin{array}{l}25 \\
(16.67)\end{array}$ & $\begin{array}{l}30 \\
(20.00)\end{array}$ & $\begin{array}{l}44 \\
(29.33)\end{array}$ & $\begin{array}{l}38 \\
(25.33)\end{array}$ & $\begin{array}{l}13 \\
(8.67)\end{array}$ & 466 & 3.11 & 4 \\
\hline \multicolumn{9}{|l|}{ Act Experience } \\
\hline $\begin{array}{l}\text { Fast Food Merchandises } \\
\text { Attract me to Purchase }\end{array}$ & $\begin{array}{l}25 \\
(16.67)\end{array}$ & $\begin{array}{l}53 \\
(35.33)\end{array}$ & $\begin{array}{l}23 \\
(15.33)\end{array}$ & $\begin{array}{l}27 \\
(18.00)\end{array}$ & $\begin{array}{l}22 \\
(14.67)\end{array}$ & 482 & 3.21 & 2 \\
\hline $\begin{array}{l}\text { Fast Food Tries to make } \\
\text { me to Think about my } \\
\text { Health Improvement }\end{array}$ & $\begin{array}{l}29 \\
(19.33)\end{array}$ & $\begin{array}{l}39 \\
(26.00)\end{array}$ & $\begin{array}{l}25 \\
(16.67)\end{array}$ & $\begin{array}{l}41 \\
(27.33)\end{array}$ & $\begin{array}{l}16 \\
(10.67)\end{array}$ & 474 & 3.16 & 3 \\
\hline $\begin{array}{l}\text { Fast Food Provides any } \\
\text { Health Improvement }\end{array}$ & $\begin{array}{l}26 \\
(17.33)\end{array}$ & $\begin{array}{l}26 \\
(17.33)\end{array}$ & $\begin{array}{l}18 \\
(12.00)\end{array}$ & $\begin{array}{l}64 \\
(42.67)\end{array}$ & $\begin{array}{l}16 \\
(10.67)\end{array}$ & 432 & 2.88 & 5 \\
\hline $\begin{array}{l}\text { Fast Food Provides me } \\
\text { growth and Maintenance } \\
\text { of Bones }\end{array}$ & $\begin{array}{l}25 \\
(16.67)\end{array}$ & $\begin{array}{l}16 \\
(10.67)\end{array}$ & $\begin{array}{l}45 \\
(30.00)\end{array}$ & $\begin{array}{l}47 \\
(31.33)\end{array}$ & $\begin{array}{l}17 \\
(11.33)\end{array}$ & 435 & 2.90 & 4 \\
\hline $\begin{array}{l}\text { Fast Food makes me to } \\
\text { Think about my Mental } \\
\text { and Physical Development }\end{array}$ & $\begin{array}{l}41 \\
(27.33)\end{array}$ & $\begin{array}{l}27 \\
(18.00)\end{array}$ & $\begin{array}{l}43 \\
(28.67)\end{array}$ & $\begin{array}{l}30 \\
(20.00)\end{array}$ & $\begin{array}{l}9 \\
(6.00)\end{array}$ & 511 & 3.41 & 1 \\
\hline
\end{tabular}

Source: Primary Data.

Table 11. Students emotional experience of consumption of fast food.

\begin{tabular}{|c|c|c|c|c|c|c|c|c|}
\hline Variables & $\begin{array}{l}\text { Strongly } \\
\text { Agree }\end{array}$ & Agree & Neutral & Disagree & $\begin{array}{l}\text { Strongly } \\
\text { Disagree }\end{array}$ & Sum & Mean & Rank \\
\hline \multicolumn{9}{|l|}{ Relate Experience } \\
\hline $\begin{array}{l}\text { Fast Food Causes me to } \\
\text { Improve the Health }\end{array}$ & $\begin{array}{l}20 \\
(13.33)\end{array}$ & $\begin{array}{l}40 \\
(26.67)\end{array}$ & $\begin{array}{l}22 \\
(14.67)\end{array}$ & $\begin{array}{l}39 \\
(26.00)\end{array}$ & $\begin{array}{l}29 \\
(19.33)\end{array}$ & 433 & 2.89 & 3 \\
\hline $\begin{array}{l}\text { Fast Food Enables me to } \\
\text { have the Sense of } \\
\text { Belonging to the Doctor }\end{array}$ & $\begin{array}{l}27 \\
(18.00)\end{array}$ & $\begin{array}{l}32 \\
(21.33)\end{array}$ & $\begin{array}{l}39 \\
(26.00)\end{array}$ & $\begin{array}{l}44 \\
(29.33)\end{array}$ & $\begin{array}{l}8 \\
(5.33)\end{array}$ & 476 & 3.17 & 2 \\
\hline $\begin{array}{l}\text { Fast Food Creates a Good } \\
\text { Relationship between me } \\
\text { and my Family }\end{array}$ & $\begin{array}{l}17 \\
(11.33)\end{array}$ & $\begin{array}{l}25 \\
(16.67)\end{array}$ & $\begin{array}{l}53 \\
(35.33)\end{array}$ & $\begin{array}{l}34 \\
(22.67)\end{array}$ & $\begin{array}{l}21 \\
(14.00)\end{array}$ & 433 & 2.89 & 3 \\
\hline $\begin{array}{l}\text { Fast Food Causes me to } \\
\text { Increase the Growing } \\
\text { Power of my }\end{array}$ & $\begin{array}{l}43 \\
(28.67)\end{array}$ & $\begin{array}{l}21 \\
(14.00)\end{array}$ & $\begin{array}{l}39 \\
(26.00)\end{array}$ & $\begin{array}{l}35 \\
(23.33)\end{array}$ & $\begin{array}{l}12 \\
(8.00)\end{array}$ & 498 & 3.32 & 1 \\
\hline Son/Daughter & & & & & & & & \\
\hline $\begin{array}{l}\text { Fast Food Provides me as } \\
\text { Balanced Nutrition in } \\
\text { Morning and Evening }\end{array}$ & $\begin{array}{l}21 \\
(14.00)\end{array}$ & $\begin{array}{l}18 \\
(12.00)\end{array}$ & $\begin{array}{l}43 \\
(28.67)\end{array}$ & $\begin{array}{l}39 \\
(26.00)\end{array}$ & $\begin{array}{l}29 \\
(19.33)\end{array}$ & 413 & 2.75 & 5 \\
\hline
\end{tabular}

Source: Primary Data. 
Table 12. Kmo and Bartlett's test students emotional experience of consumption of fast food.

\begin{tabular}{cc}
\hline Kaiser-Meyer-Olkin Measure of Sampling Adequacy & 0.895 \\
Bartlett's Test of Sphericity Approx. Chi-Square & 3303.181 \\
DF & 300 \\
Sig & 0.000 \\
\hline
\end{tabular}

Level of Significance at 5 per cent.

Table 13. Rotated component matrix students emotional experience of consumption of fast food.

\begin{tabular}{|c|c|c|c|c|c|}
\hline \multirow{2}{*}{ Variables } & \multicolumn{5}{|c|}{ Factors } \\
\hline & F1 & F2 & F3 & F4 & F5 \\
\hline \multicolumn{6}{|l|}{ Sense Experience } \\
\hline $\mathrm{X}_{1}$-Quality of Fast Food is Really Good & - & 0.588 & - & - & - \\
\hline $\mathrm{X}_{2}$-Creation of Fast Food are Simple & - & 0.656 & - & - & - \\
\hline $\begin{array}{l}X_{3} \text {-Fast Food Assure Your Health in the } \\
\text { form Good Strength }\end{array}$ & - & 0.625 & - & - & - \\
\hline $\begin{array}{l}\mathrm{X}_{4} \text {-The Overall Performance of Fast } \\
\text { Food Let You Feel Joyfully Satisfies }\end{array}$ & - & - & 0.680 & - & - \\
\hline $\mathrm{X}_{5}$-The Minimum Quantity of Fast & & & & & \\
\hline $\begin{array}{l}\text { Food Can Enough one Time Lunch or } \\
\text { Snacks }\end{array}$ & - & - & - & 0.572 & - \\
\hline \multicolumn{6}{|l|}{ Feel Experience } \\
\hline $\begin{array}{l}\mathrm{X}_{6} \text {-The Consuming of Fast Food Let me } \\
\text { have Warm Feelings }\end{array}$ & - & - & 0.732 & - & - \\
\hline $\mathrm{X}_{7}$-The Status Attitude of Fast Food lets & & & & & \\
\hline $\begin{array}{l}\text { Consumers Satisfy and Receive the } \\
\text { Respect }\end{array}$ & - & 0.621 & - & - & - \\
\hline $\begin{array}{l}\mathrm{X}_{8} \text {-Usage of Fast Food Lets People Feel } \\
\text { that is in Keeping with the Fashion }\end{array}$ & - & 0.712 & - & - & - \\
\hline $\mathrm{X}_{9}$-The Whole Performance of Fast & & & & & \\
\hline $\begin{array}{l}\text { Food has not Affected my Mood } \\
\text { Response }\end{array}$ & - & - & - & 0.818 & - \\
\hline $\begin{array}{l}\mathrm{X}_{10} \text {-The Variety of Fast Food Provides } \\
\text { me in a Nourishing and Delicious Taste }\end{array}$ & - & - & 0.583 & - & - \\
\hline \multicolumn{6}{|l|}{ Think Experience } \\
\hline $\mathrm{X}_{11}$-Fast Food can Stimulate my Curiosity & - & - & - & 0.522 & - \\
\hline $\begin{array}{l}\mathrm{X}_{12} \text {-Fast Food Make Consumers Feel } \\
\text { Surprising }\end{array}$ & - & - & - & - & 0.765 \\
\hline $\begin{array}{l}\mathrm{X}_{13} \text {-Fast Food can Stimulate me the } \\
\text { thinking of Other Related thing Like } \\
\text { Health Immune System and Source of } \\
\text { Energy etc. ... }\end{array}$ & - & 0.577 & - & - & - \\
\hline $\begin{array}{l}\mathrm{X}_{14} \text {-Fast Food can Stimulate my } \\
\text { Imagination }\end{array}$ & 0.741 & - & - & - & - \\
\hline $\begin{array}{l}\mathrm{X}_{15} \text {-Fast Food can Stimulate my Creative } \\
\text { thinking }\end{array}$ & 0.604 & - & - & - & - \\
\hline
\end{tabular}

Level of Significance: 5 per cent. 
Table 14. Rotated component matrix students emotional experience of consumption of fast food.

\begin{tabular}{|c|c|c|c|c|c|}
\hline \multirow{2}{*}{ Variables } & \multicolumn{5}{|l|}{ Factors } \\
\hline & Strongly Agree & Agree & Neutral & Disagree & Strongly Disagree \\
\hline \multicolumn{6}{|l|}{ Act Experience } \\
\hline $\mathrm{X}_{16}$-Fast Food Merchandises Attract me to Purchase & - & - & - & - & 0.598 \\
\hline $\begin{array}{l}\mathrm{X}_{17} \text {-Fast Food Tries to make me to Think about my Health } \\
\text { Improvement }\end{array}$ & 0.827 & - & - & - & - \\
\hline $\mathrm{X}_{18}$-Fast Food Provides any Health Improvement & 0.639 & - & - & - & - \\
\hline $\mathrm{X}_{19}$-Fast Food Provides me growth and Maintance of Bones & 0.883 & - & - & - & - \\
\hline $\begin{array}{l}\mathrm{X}_{20} \text {-Fast Food makes me to Think about my Mental and Physical } \\
\text { Development }\end{array}$ & 0.707 & - & - & - & - \\
\hline \multicolumn{6}{|l|}{ Relate Experience } \\
\hline $\mathrm{X}_{21}$-Fast Food Causes me to Improve the Health & 0.805 & - & - & - & - \\
\hline $\begin{array}{l}\mathrm{X}_{22} \text {-Fast Food Enables me to have the Sense of Belonging to the } \\
\text { Doctor }\end{array}$ & 0.699 & - & - & - & - \\
\hline $\begin{array}{l}\mathrm{X}_{23} \text {-Fast Food Creates a Good Relationship between me and my } \\
\text { Family }\end{array}$ & 0.575 & - & - & - & - \\
\hline $\begin{array}{l}\mathrm{X}_{24} \text {-Fast Food Causes me to Increase the Growing Power of my } \\
\text { Son/Daughter }\end{array}$ & 0.658 & - & - & - & - \\
\hline $\begin{array}{l}\mathrm{X}_{25} \text {-Fast Food Provides me as Balanced Nutrition in Morning and } \\
\text { Evening }\end{array}$ & - & 0.671 & - & - & - \\
\hline Eigen Value & 10.104 & 2.728 & 1.995 & 1.525 & 1.357 \\
\hline$\%$ of Variance & 56.416 & 10.911 & 7.982 & 6.100 & 5.428 \\
\hline Cumulative & 56.416 & 67.327 & 75.308 & 81.408 & 86.836 \\
\hline
\end{tabular}

Level of Significance at 5 per cent.

Table 15. Summary of rotation factor analysis \& Cronbach's alpha students emotional experience of consumption of fast food.

\begin{tabular}{lll}
\hline Factors & Variables incorporated in the factors & Cronbach's \\
& $\begin{array}{l}\text { Fast food can stimulate my imagination, fast food can stimulate my creative thinking, fast food tries to } \\
\text { make me to think about my health improvement, fast food provides any health improvement, fast food } \\
\text { provides me growth and maintenance of bones, fast food makes me to think about my mental and physical } \\
\text { development, fast food causes me to improve the health, fast food enables me to have the sense of belonging } \\
\text { to the doctor, fast food creates a good relationship between me and my family and fast food causes me to } \\
\text { increase the growing power of my son/daughter }\end{array}$ \\
\hline Atrongly Agree & $\begin{array}{l}\text { Quality of fast food is really good, creation of fast food are simple, fast food assure your health in the form } \\
\text { good strength, the status attitude of fast food lets consumers satisfy and receive the respect, usage of fast } \\
\text { food lets people feel that is in keeping with the fashion, fast food can stimulate me the thinking of other } \\
\text { related thing like health immune system and source of energy etc. ... and fast food provides me as balanced } \\
\text { nutrition in morning and evening }\end{array}$ & 0.897 \\
\hline Neutral & $\begin{array}{l}\text { The overall performance of fast food let you feel joyfully satisfies, the consuming of fast food let me have } \\
\text { warm feelings and the variety of fast food provides me in a nourishing and delicious taste }\end{array}$ & 0.855 \\
\hline Disagree & $\begin{array}{l}\text { The minimum quantity of fast food can enough one time lunch or snacks and fast food can stimulate my } \\
\text { curiosity }\end{array}$ & 0.845 \\
\hline Strongly Disagree & Fast food make consumers feel surprising and fast food merchandises attract me to purchase & 0.837 \\
\hline
\end{tabular}

Source: Computed From Primary Data. 
The result of rotation factor analysis shows that the Cronbach's Alpha value $0.946,0.897,0.855,0.845$, and 0.837 establishes considerable and optimistic association between the variables tested. It establishes the existence of internal constancy with information collected at time of survey. Thus it completes that there exists vital association between variables enclosed within the factors of consumption of fast food by the college students' and their emotional experiences.

From the elaborate data analysis it is established that greater part of the respondents procure fast food for time saving purpose, it is graded in the first position with the mean score of 3.60 .

\section{Suggestion}

In the present scenario, the performance and perception of fast food has gradually more become admired among youthful people and teenagers. In 1990's the fast food industry is valued and estimated around 1000 crores, and is still growing [7]. This report especially shows that the fast food utilization habits of younger are particularly college students in sultanate of Oman. Consumer attitudes towards fast food are mainly inclined by quality attributes. As it is observed that the sample consumers give emphasis to taste, hygiene, different varieties and emotional satisfaction of the product at the time of consuming fast food. So, it is recommended that the fast food manufacturers and sellers should focus their experiential marketing.

\section{Conclusion}

The key input to make complete loyalty is developing a reliable and distinguished complete brand perception through the relationship of specific emotional experiences with a product or service. Emotions and feelings have long been familiar as important factors in spending and consumer decision making. The utilization of fast food products is changing due to financial viability and personal factors. Clanging consumerism is the biggest factor that plays a major role in consumers buying behaviour. Experiential marketing techniques help companies to generate relationships with clients and join them all the way through distinct and remarkable practices in the day to day life. Finally it concludes that considering various components for the study, greater part of the consumers provides importance to freshness, hygiene, and taste, healthy products are grouped as first factor, and it accounts for $38.499 \%$ of the total variance.

\section{Acknowledgements}

We might want to thank the administration of Sur University College for giving chances and assets to doing this exploration work and for the examination exercises. Likewise, the creators thank the Dean of Sur University College and associates for the consistent help and support to complete this exploration work. 


\section{Conflicts of Interest}

The authors declare no conflicts of interest regarding the publication of this paper.

\section{References}

[1] El Ansari, W., Stock, C. and Mikkolajczyk, R.T. (2011) Relationships between Food Consumption and Living Arrangements among University Students in Four European Countries-A Cross-Sectional Study. Nutritional Journal, 11, 28. https://doi.org/10.1186/1475-2891-11-28

[2] Kolodinsky, J., Harvey-Berino, J.R., Berlin, L., Johnson, R.K. and Reynolds, T.W. (2007) Knowledge of Current Dietary Guidelines and Food Choice by College Students: Better Eaters Have Higher Knowledge of Dietary Guidance. Journal of the Academy of Nutrition and Dietetics, 107, 1409-1413. https://doi.org/10.1016/j.jada.2007.05.016

[3] Sivapriyaa, T. (2014) Study on the Consumption Pattern of Fast Food among University Students. Global Journal of Engineering Science and Research Management, 1, 1-10.

[4] Oonurlubaş, E. (2013) Fast Food Consumption Habits of University Students. Journal of Food Agriculture and Environment, 11, 12-14.

[5] https://pos.toasttab.com/blog/10-fast-food-industry-statistics/amp

[6] Broccia, F., Lantini, T., Lucianni, A. and Carcassi, A.M. (2008) Nutrition Knowledge of Sardinian and Corsican University Students. Annali di igiene, 20, 49-55.

[7] Islam, N. and Ullah, G.M.S. (2010) Factors Affecting Consumers' Preferences on Fast Food Items in Bangladesh. Journal of Applied Business Research, 26, 131-146. https://doi.org/10.19030/jabr.v26i4.313

[8] Bipasha, M.S. and Goon, S. (2013) Fast Food Preferences and Food Habits among Students of Private Universities in Bangladesh. South East Asia Journal of Public Health, 3, 61-64. https://doi.org/10.3329/seajph.v3i1.17713

[9] Chowdhury, R. and Subho, R.H. (2018) Impact of Fast Food Consumption on Health: A Study on University Students of Bangladesh. 201821 st International Conference of Computer and Information Technology, Dhaka, Bangladesh, 21-23 December 2018, 1-6. https://doi.org/10.1109/ICCITECHN.2018.8631962

[10] Poppkin, B. (2001) The Nutrition Transition and Obesity in the Developing World. The Journal of Nutrition, 131, 871S-873S. https://doi.org/10.1093/jn/131.3.871S

[11] Anita, G. and Singh, N.P. (2008) Consumer Perception about Fast Food in India: An Exploratory Study. British Food Journal, 109, 182-195. https://doi.org/10.1108/00070700710725536

[12] Akbay, C., Tiryaki, G.T. and Gui, A. (2007) Consumer Behavior of Influencing Fast Food Consumption in Turkey. Food Control, 18, 904-913.

[13] Denney-Wilson, E., Crawford, D., Dobbins, T., Hardy, L. and Okely, A.D. (2009) Influences on Buyers Consumption of Soft Drinks and Fast Foods in Adolescents. Asia Pacific Journal of Clinical Nutrition, 18, 447-452.

[14] Bala, S.M., Anil Kumar, T. and Srinivaasa, R.K. (2012) Buying Behaviour of Consumers towards Instant Food Products. International Journal of Research and Computational Technology, 2, 1-13.

[15] Dani, V.V. and Pabalkar, V. (2013) Examining of Consumer Behaviour towards Fast Food Industry in Pune. 
[16] Anand, R. (2011) A Study of Determinants Impacting Consumers Food Choice with Reference to the Fast Food Consumption in India. Society and Business Review, 6, 176-187. https://doi.org/10.1108/17465681111143993 